\title{
Uji daya hambat ekstrak etanol daun srikaya (Annona squamosa) terhadap pertumbuhan bakteri Escherichia coli dan Staphylococcus aureus
}

\author{
${ }^{1}$ Alberta Y. M. Tansil \\ ${ }^{2}$ Edward Nangoy \\ ${ }^{2}$ Jimmy Posangi \\ ${ }^{2}$ Robert A. Bara
}

\author{
${ }^{1}$ Kandidat Skripsi Fakultas Kedokteran Universitas Sam Ratulangi Manado \\ ${ }^{2}$ Bagian Farmakologi dan Terapi Fakultas Kedokteran Universitas Sam Ratulangi Manado \\ Email: albertayoshe134@gmail.com
}

\begin{abstract}
Srikaya leaf contains terpenoid, polyphenol, alkaloid, and flavonoid that can potentially be an antibacterial. This study was aimed to obtain the potency of srikaya leaf extract against Staphylococcus aureus (ATCC25923) and Escherichia coli (ATCC11229). This was an experimental laboratory study using the Kirby-Bauer modified well diffusion technique in the Phytochemistry and Microbiology Laboratory of MIPA Faculty at Sam Ratulangi University. Srikaya leaf extract was obtained by using ethanol maceration technique. The concentrations of the extract were as follows: $50 \%, 25 \%$, and $12.5 \%$. Ciprofloxacin was used as the positive control while CMC as the negative one. The results showed that CMC did not have any inhibition zone around the well. Ciprofloxacin showed the largest mean diameters of inhibition zones: $35.78 \mathrm{~mm}$ against E.coli and $36.55 \mathrm{~mm}$ against S.aureus. The mean diameters of inhibition zones of Srikaya leaf extract 50\% were $9.13 \mathrm{~mm}$ against E.coli and $13.78 \mathrm{~mm}$ against S.aureus. The mean diameters of inhibition zones of Srikaya leaf extract $25 \%$ were $7.8 \mathrm{~mm}$ against E.coli and $13.55 \mathrm{~mm}$ agaisnt S.aureus. Meanwhile, the mean diameters of inhibition zones of srikaya leaf extract $12.5 \%$ were $7.05 \mathrm{~mm}$ against E.coli and $11.31 \mathrm{~mm}$ agaimst S.aureus. Conclusion: Srikaya leaf extract could potentially inhibit the growth of S.aureus and E.coli. The srikaya leaf extract could inhibit S.aureus more effectively than E.coli.
\end{abstract}

Keyword: antibacterial, srikaya leaf extract, Staphylococcus aureus, Escherichia coli

\begin{abstract}
Abstrak: Daun Srikaya mengandung terpenoid, fenolik, alkaloid, dan flavonoid yang berpotensi sebagai antibakteri. Penelitian ini bertujuan untuk mengetahui uji daya hambat ekstrak daun srikaya terhadap Staphylococcus aureus (ATCC25923) dan Escherichia coli (ATCC11229). Jenis penelitian ialah eksperimental laboratorium dengan modifikasi Kirby-Bauer sumuran di Laboratorium Fitokimia dan Mikrobiologi Fakultas MIPA Universitas Sam Ratulangi. Ekstrak daun srikaya diperoleh dari proses maserasi dengan etanol 96\%. Konsentrasi ekstrak kental yang digunakan ialah 50\%, 25\%, 12,5\%. Siprofloksasin digunakan sebagai kontrol positif dan CMC sebagai kontrol negatif. Hasil penelitian mendapatkan CMC tidak mempunyai zona hambat. Siprofloksasin memiliki diameter zona hambat yang paling besar. Rerata diameter zona hambat yang dihasilkan oleh siprofloksasin ialah $35,78 \mathrm{~mm}$ terhadap bakteri E.coli dan $36,55 \mathrm{~mm}$ terhadap S.aureus. Rerata diameter zona hambat ekstrak daun srikaya $50 \%$ ialah $9,13 \mathrm{~mm}$ terhadap E.coli dan $13,78 \mathrm{~mm}$ terhadap bakteri S.aureus. Rerata diameter zona hambat ekstrak daun srikaya $25 \%$ ialah 7,8 mm terhadap E.coli dan 13,25 mm terhadap S.aureus. Rerata diameter zona hambat ekstrak daun srikaya 12,5\% ialah 7,05 mm terhadap E.coli dan $11,31 \mathrm{~mm}$ terhadap S.aureus. Simpulan: Ekstrak daun srikaya berpotensi memiliki efek daya hambat terhadap pertumbuhan bakteri S.aureus dan E.coli. Daya hambat ekstrak daun srikaya lebih besar terhadap S.aureus daripada E.coli.
\end{abstract}

Kata kunci: antibakteri, ekstrak daun srikaya, Staphylococcus aureus, Escherichia coli 
Daun srikaya (Annona squamosa) dikenal oleh masyarakat Alor Utara di Nusa Tenggara Timur sebagai tanaman obat tradisional untuk mengobati berbagai penyakit. Bagian daun dari tumbuhan ini digunakan untuk mengatasi batuk, rematik, gangguan saluran pencernaan (diare, disentri, perut kembung), penyakit kulit (borok, bisul, kudis), menambah stamina, serta pereda demam. ${ }^{1}$

Daun srikaya mengandung tanin, fenolik, polifenol, glikosida, saponin, karbohidrat, protein, fitosterol, asam amino, alkaloid, dan flavonoid., ${ }^{2,3}$ Terpenoid, alkaloid,flavonoid, dan fenolik telah dikenal berpotensi sebagai antibakteri dan antifungal. ${ }^{4}$

Enterotoksin Escherichia coli dan Staphylococcus aureus merupakan penyebab diare pada anak di negara berkembang. ${ }^{5}$

Penelitian ini bertujaun untuk mengetahui apakah daun Annona squamosa Linn mempunyai efek antibakteri terhadap Escherichia coli dan Staphylococcus aureus.

\section{METODE PENELITIAN}

Jenis penelitian ini ialah eksperimental laboratorium yang dilakukan di Laboratorium Fitokimia dan Mikrobiologi Program Studi Farmasi FMIPA Universitas Sam Ratulangi. Penelitian ini dilaksanakan pada bulan Agustus sampai dengan November 2016.

Tahap-tahap penelitian ialah sterilisasi alat, pembuatan ekstrak daun srikaya dengan cara maserasi, pembuatan media peremajaan Nutrient Agar (NA), MullerHinton Agar (MHA), suspensi bakteri dan pengujian bakteri. Siprofloksasin sebagai kontrol positif sedangkan Carboxy Methyl Celullose (CMC) sebagai kontrol negatif. Ekstrak daun srikaya dengan beberapa konsentrasi $(50 \%, 25 \%, 12,5 \%)$, kontrol positif, dan kontrol negatif diteteskan sebanyak $50 \mu \mathrm{l}$ pada sumur yang berbeda, kemudian cawan Petri dimasukkan dalam inkubator pada suhu $37^{\circ} \mathrm{C}$ selama 24 jam. Diamati dan diukur diameter zona hambat yang terbentuk dengan menggunakan mistar selama 3 hari.
Zona bening merupakan petunjuk kepekaan bakteri terhadap bahan antibakteri yang digunakan sebagai bahan uji dan dinyatakan dengan diameter zona hambat. Diameter zona hambat dapat diukur dengan rumus :

$$
\left(\frac{\mathrm{Dh}+\mathrm{Dv}}{2}\right)-\mathrm{Ds}
$$

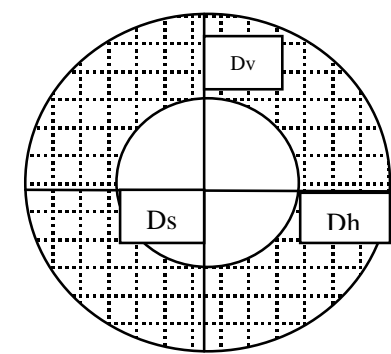

$$
\begin{array}{ll}
\text { Dh } & \text { : Diameter horizontal } \\
\text { Dv } & \text { : Diameter vertikal } \\
\text { Ds } & \text { : Diameter sumuran } \\
& \text { : Zona hambat }
\end{array}
$$

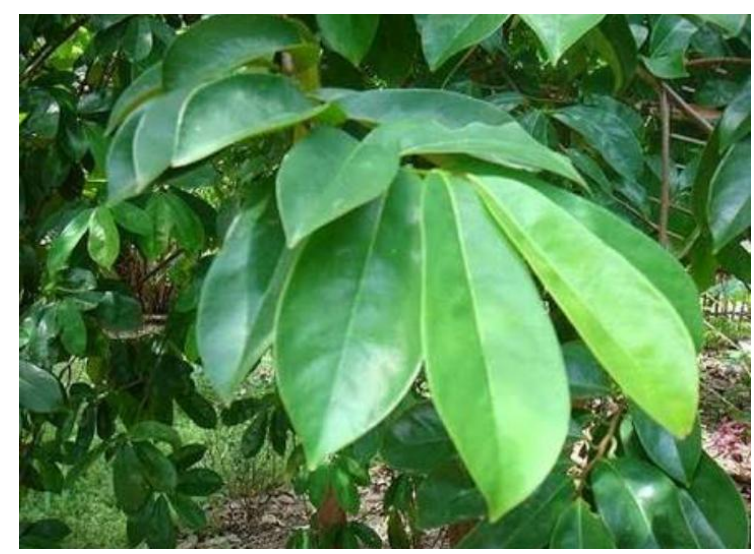

Gambar 1. Daun srikaya yang digunakan dalam penelitian

\section{HASIL PENELITIAN}

Hasil pengujian daya hambat ekstrak daun srikaya terhadap pertumbuhan Staphylococcus aureus dan Escherichia coli pada pengamatan $3 \times 24$ jam inkubasi dengan 3 kali pengulangan memiliki nilai positif. Hal ini ditunjukkan dengan adanya clear zone disekitar sumuran kontrol positif dan ekstrak daun srikaya. Sekitar sumuran kontrol negatif tidak terbentuk clear zone.

Pengamatan hari pertama dilakukan pada waktu inkubasi 24 jam, yaitu pukul 14.15 WITA. Pengamatan hari kedua 
dilakukan pada waktu inkubasi 18 jam, ketiga dilakukan pada waktu inkubasi 24 yaitu pukul 14.30 WITA. Pengamatan hari jam, yaitu pukul 14.45 WITA.

Tabel 1. Diameter zona hambat kontrol dan perlakuan pada bakteri E.coli dan S.aureus pada hari pertama

\begin{tabular}{llcrll|lrrrc}
\hline \multicolumn{1}{c}{ P } & \multicolumn{4}{c|}{ Staphylococcus aureus } & \multicolumn{5}{c}{ Escherichia coli } \\
& $\mathrm{K}-$ & $\mathrm{K}+$ & $50 \%$ & $25 \%$ & $12,5 \%$ & $\mathrm{~K}-$ & $\mathrm{K}+$ & $50 \%$ & $25 \%$ & $12,5 \%$ \\
\hline I & 0 & 36,65 & 17,85 & 14,60 & 12,9 & 0 & 37,65 & 10,10 & 7,65 & 7,90 \\
II & 0 & 34,25 & 12,65 & 12,05 & 11,8 & 0 & 32,35 & 8,25 & 7,15 & 7,00 \\
III & 0 & 38,75 & 10,85 & 13,10 & 9,25 & 0 & 37,35 & 9,05 & 8,60 & 6,25 \\
Rerata & 0 & 36,55 & 13,78 & 13,25 & 11,31 & 0 & 35,78 & 9,13 & 7,8 & 7,05 \\
\hline
\end{tabular}

Keterangan : P. pengulangan; K-. kontrol negatif; K+. kontrol positif; 50\%. konsentrasi 50\%; 25\%. konsentrasi $25 \% ; 12,5 \%$. konsentrasi $12,5 \%$.

Tabel 2. Diameter zona hambat kontrol dan perlakuan pada bakteri E.coli dan S.aureus pada hari kedua

\begin{tabular}{lccccc|ccccc}
\hline \multicolumn{1}{c}{ P } & \multicolumn{4}{c|}{ Staphylococcus aureus } & \multicolumn{5}{c}{ Escherichia coli } \\
& $\mathrm{K}-$ & $\mathrm{K}+$ & $50 \%$ & $25 \%$ & $12,5 \%$ & $\mathrm{~K}-$ & $\mathrm{K}+$ & $50 \%$ & $25 \%$ & $12,5 \%$ \\
\hline I & 0 & 27,10 & 7,15 & 6,60 & 5,60 & 0 & 30,80 & 6,00 & 1,65 & 1,48 \\
II & 0 & 30,35 & 6,80 & 6,65 & 5,80 & 0 & 28,75 & 7,10 & 1,50 & 1,00 \\
III & 0 & 28,90 & 7,60 & 7,15 & 5,75 & 0 & 26,60 & 5,20 & 0,89 & 0,65 \\
Rerata & 0 & 28,78 & 7,18 & 6,8 & 5,71 & 0 & 28,05 & 6,1 & 1,34 & 1,04 \\
\hline
\end{tabular}

Tabel 3. Diameter zona hambat kontrol dan perlakuan pada bakteri E.coli dan S.aureus pada hari ketiga

\begin{tabular}{llcccc|ccccc}
\hline \multicolumn{1}{c}{ P } & \multicolumn{4}{c|}{ Staphylococcus aureus } & \multicolumn{5}{c}{ Escherichia coli } \\
& $\mathrm{K}-$ & $\mathrm{K}+$ & $50 \%$ & $25 \%$ & $12,5 \%$ & $\mathrm{~K}-$ & $\mathrm{K}+$ & $50 \%$ & $25 \%$ & $12,5 \%$ \\
\hline I & 0 & 24,15 & 3,15 & 2,55 & 2,30 & 0 & 21,00 & 3,15 & 0,7 & 0,55 \\
II & 0 & 25,75 & 3,20 & 1,60 & 1,15 & 0 & 21,65 & 6 & 0,6 & 0,2 \\
III & 0 & 26,95 & 3,75 & 3,30 & 0,55 & 0 & 21,05 & 3,5 & 0,5 & 0,1 \\
Rerata & 0 & 25,61 & 3,36 & 2,48 & 1,33 & 0 & 21,23 & 4,21 & 0,6 & 0,28 \\
\hline
\end{tabular}

\section{BAHASAN}

Pada hari pertama kelompok kontrol positif, yaitu siprofloksasin memperlihatkan rerata zona hambat yang paling besar (Tabel 1). Siprofloksasin merupakan antibiotik spektrum luas sehingga dapat membunuh bakteri Gram positif dan Gram negatif. Hal ini mungkin yang menyebabkan zona hambat antara E.coli dan S.aureus tidak berbeda jauh. Mekanisme kerja utama siprofloksasin, yaitu menghambat replikasi bakterial DNA dengan mengintervensi aktivasi DNA Girase (Topoisomerase II) dan Topoisomerase IV selama pertumbuhan dan reproduksi bakteri. Penghambatan terhadap enzim yang terlibat dalam replikasi (peristiwa penggandaan DNA sebelum pembelahan sel berlangsung), rekombinasi (penggabungan gen dari satu atau lebih sel ke sel target), dan reparasi (perbaikan) DNA tersebut mengakibatkan penghambatan terhadap pertumbuhan sel bakteri. ${ }^{6}$

Berdasarkan pengamatan hari pertama, kontrol negatif tidak memperlihatkan adanya zona hambat di sekitar sumuran. Hal ini diduga karena CMC tidak bereaksi dengan senyawa organik sehingga tidak ada reaksi yang terbentuk. ${ }^{7}$ Pengamatan ini 
diperkuat dengan penelitian yang dilakukan oleh Mpila $^{8}$ (2012) pada uji aktivitas antibakteri ekstrak etanol daun mayana (Coleus atropurpureus benth) terhadap Staphylococcus aureus, Escherichia coli dan Pseudomonas aeruginosa secara invitro dan Dewi ${ }^{9}$ (2010) yang meneliti aktivitas antibakteri ekstrak etanol buah mengkudu (Morinda citrifolia Linn) terhadap bakteri pembusuk daging segar pada kontrol negatifnya, yaitu CMC tidak didapatkan zona hambat. Hal ini dapat membuktikan bahwa larutan pengencer tidak memengaruhi pertumbuhan bakteri.

Pada penelitian ini, ekstrak daun srikaya dibagi menjadi tiga konsentrasi, yaitu $50 \%, 25 \%, 12,5 \%$. Zona hambat yang terbentuk pada setiap konsentrasi ekstrak daun srikaya ini tidak sama dan semakin menurun seiring menurunnya konsentrasi $(50 \%>25 \%>12,5 \%)$. Hasil penelitian ini sesuai dengan penelitian yang dilakukan oleh Neethu et al. ${ }^{10}$ (2016) tentang aktivitas fitokimia dan efek antibakteri ekstrak daun srikaya, yang menyatakan semakin tinggi konsentrasi daun srikaya maka semakin tinggi aktivitas bakterialnya. Peningkatan daya hambat ektrak ini mungkin dapat disebabkan oleh semakin tinggi konsentrasi ekstrak maka akan semakin tinggi kandungan senyawa zat antibakteri yang terkandung di dalam ekstrak sehingga dapat menghambat pertumbuhan bakteri lebih maksimal.

Zona hambat yang terbentuk di sekitar sumur yang diberi ekstrak daun srikaya menunjukkan kandungan yang terdapat pada daun srikaya mampu menghambat pertumbuhan S.aureus dan E.coli. Lebar diameter zona hambat yang terbentuk di sekitar sumur dapat dijadikan sebagai parameter untuk melihat kekuatan senyawa bioaktif yang terkandung dalam ekstrak daun srikaya. Semakin luas zona hambat yang terbentuk maka semakin kuatnya senyawa bioaktif menghambat pertumbuhan bakteri. $^{10}$

Bakteri Gram positif memiliki struktur dinding sel dengan lebih banyak peptideglikan, sedikit lipid dan dinding sel mengandung polisakarida (asam teikoat).
Asam teikoat merupakan polimer yang larut dalam air, yang berfungsi sebagai transpor ion positif untuk keluar atau masuk. Sifat larut dalam air inilah yang menunjukkan bahwa dinding sel bakteri Gram positif bersifat lebih polar. Bakteri Gram negatif lebih banyak mengandung lipid, sedikit peptidoglikan, membran luar berupa bilayer (berfungsi sebagai pertahanan selektif senyawa-senyawa yang keluar atau masuk sel dan menyebabkan efek toksik). Membran luar terdiri dari fosfolipid (lapisan dalam), dan lipopolisakarida (lapisan luar) tersusun atas lipid A yang bersifat nonpolar. Perbedaan struktur dinding sel menentukan penetrasi, ikatan dan aktivitas senyawa antibakteri. ${ }^{11}$

Senyawa flavonoid dalam daun srikaya merupakan bagian yang bersifat polar sehingga ekstrak srikaya lebih mudah menembus lapisan peptidoglikan yang bersifat polar daripada lapisan lipid yang nonpolar. Hal ini mungkin menyebabkan zona hambat ekstrak terhadap bakteri S.aureus lebih luas daripada E.coli. ${ }^{12}$ Flavonoid bekerja sebagai antibakteri melalui beberapa mekanisme, seperti mengintervensi membran sitoplasma; serta menghambat sintesis asam nukleat, metabolisme energi, sintesis dinding sel, dan sintesis membran sel. Kemungkinan flavonoid merupakan zat yang paling kuat dalam ekstrak daun srikaya. ${ }^{13}$

Mekanisme tanin sebagai antibakteri diduga karena tanin bersifat astringen, mempercepat penyembuhan radang dan luka pada membran mukosa. ${ }^{5}$ Zona hambat ektrak daun srikaya terlihat berwarna kecoklatan. Hal ini diduga berasal dari warna tanin yang coklat. ${ }^{14}$

Berdasarkan hasil pengamatan selama 3 hari, tidak didapatkan pertambahan zona hambat ektrak daun srikaya terhadap pertumbuhan bakteri E.coli atau S.aureus. Bahkan sebaliknya, didapatkan pertumbuhan bakteri pada zona hambat. Hal ini mungkin disebabkan senyawa bioaktif daun srikaya bersifat bakteriostatik yaitu menghambat pertumbuhan mikroba tetapi tidak membunuh yang ditandai dengan zona hambat yang ditumbuhi kembali oleh 
bakteri setelah masa inkubasi lebih dari 24 jam. ${ }^{15}$

\section{SIMPULAN}

Ekstrak daun srikaya berpotensi berefek antibakteri dalam menghambat pertumbuhan bakteri $S$. aureus dan E. coli. Daya hambat ekstrak daun srikaya lebih besar terhadap S.aureus daripada terhadap E.coli.

\section{DAFTAR PUSTAKA}

1. Usman MH. Etnobotani pemanfaatan tumbuhan obat oleh masyarakat Kecamatan Alor Tengah Utara Kabupaten Alor Nusa Tenggara Timur [Skripsi]. Malang: Universitas Islam Negeri (UIN) Maulana Malik Ibrahim Malang; 2011.

2. Vanitha V, Umadevi KJ, Vijayalakshmi K. Determination of bioactive components of Annona squamosa L leaf by GC-MS analysis. IJRPC. 2011;3(4):309-12.

3. Purwaningsih NV. Daya bunuh ekstrak daun srikaya (Annona Squamosa L.) terhadap telur dan larva Aedes aegypti [Tesis]. [Denpasar]: Universitas Udayana; 2015.

4. Saxena M, Saxena J,Nema R, Singh D, Gupta A. Phytochemistry of medicinal plants. J Pharmacogn Phytochem. 2013;1(6):170.

5. Camilleri A, Murray JA. Infeksi saluran cerna. In: Longo DL, Fauci AS, editors. Harrison Gastroenterologi dan Hepatologi. Jakarta: EGC, 2014; p. 214.

6. Brunton LL, Lazo JS, Parker LK. Goodman and Gilman's The Pharmacological Basis of Therapeutics. Newyork: McGraw-Hill, 2006; p. 1119-22.
7. Anonymous [monograph on pdf]. Carboxymethyl Cellulose. FAO, 1989.

8. Mpila DA. Uji aktivitas antibakteri ekstrak etanol daun mayana (Coleus atropurpureus [L] Benth) terhadap Staphylococcus aureus, Escherichia coli dan Pseudomonas aeruginosa secara invitro [Skripsi]. Manado: Universitas Sam Ratulangi; 2012.

9. Dewi FK. Aktivitas antibakteri ekstrak etanol buah mengkudu (Morinda citrifolia Linn) terhadap bakteri pembusuk daging segar [Skripsi]. Surakarta: Universitas Sebelas Maret; 2010.

10. Neethu SK, Santhoshkumar R. Phytochemical analysis and antimicrobial activities of Annona squamosa (L) leaf extracts. J Pharmacogn Phytochem. 2016;5(4): 128-31.

11. Nithiya T, Vijayalakshmi R. Antimicrobial activity of fruit extract of Annona squamosa L. WJPPS. 2015; 4(5):125767.

12. Zheng T.X, Qiang Z, Hong Y.Z. Identifying antibacterial targets of flavonoids by comparative genomics and molecular modeling. Genomics. 2014;3(1).

13. Tim CT, Lamb AJ. Antimicrobial activity of flavonoids. IJAA. 2005;26:343-56.

14. Khanbabaee K, Teunis VR. Tannins: Classification and definition. Nat Prod Rep. 2001;18:641-9.

15. Sakinah N. Uji aktivitas sediaan obat kumur ekstrak daun Miana coleus scutellarioides (L.) Benth terhadap pertumbuhan bakteri Streptococcus mutans [Skripsi]. Makasar: Universitas Hasanuddin; 2015. 